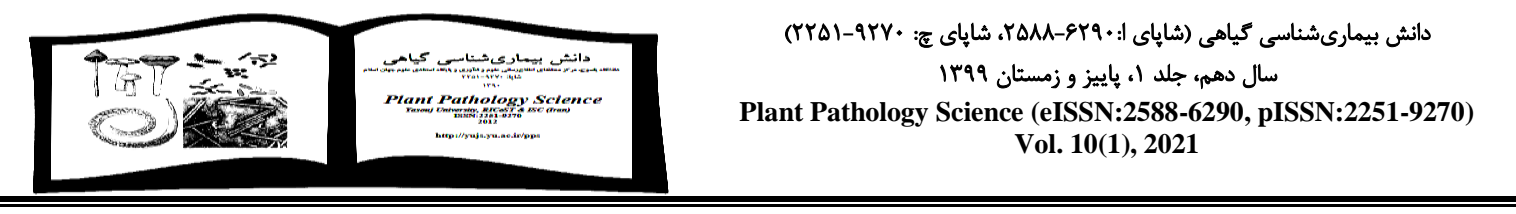

Extensional Article

\title{
Control methods of plant pathogens in irrigation system
}

\author{
EISA NAZERIAN ${ }^{1}$, SAHAR SAYAD ${ }^{2}$
}

1. Agricultural Research Education and Extension Organization, Horticultural Research Institute, Ornamental Plants Research Center, Mahalat, Iran

2. Union of Flowers and Ornamental Plants, Tonokabon, Ramsar, Iran

Received: 22.10.2020

Accepted: 01.03.2021

Nazerian E, Sayad S (2021) Control methods of plant pathogens in irrigation system. Plant Pathology Science 10(1): 117-127. Doi: 10.2982/PPS.10.1.117.

\begin{abstract}
Many plant pathogens can spread into irrigation water in farms, gardens or greenhouses and cause disease in various crops. So far, a large number of plant pathogens including 43 fungal-like organisms, 27 fungi, eight bacteria, 26 viruses and 13 nematodes have been isolated and reported from water sources and water transmission systems. In many greenhouses, various pesticides are used to prevent the spread and control of these pathogens, which imposes costs, soil or water pollution, and the possibility of resistance in pathogens. Different methods of water treatment to control aquatic pathogens in the irrigation system using chemicals such as chlorine, chlorine dioxide, copper, silver and ozone, physical methods such as water filtration, heat, ultraviolet rays and the use of biosurfactants such as rhamnolipid and nitrapyrin, are described in this article.
\end{abstract}

Key words: Water treatment, Plant pathogens, Biofilm 
مقاله ترويجى

\title{
روشهاى مبارزه با بيماركرهاى كياهى در سيستم آبيارى
}

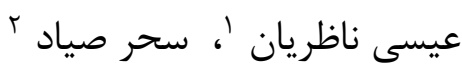 \\ 1. سازمان تحقيقات، آموزش و ترويج كشاورزى، موسسه تحقيقات علوم باغبانى، \\ يزوهشكده گل و گياهان زينتى، محلات

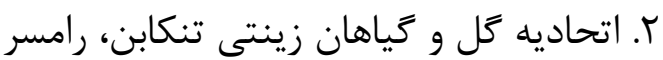

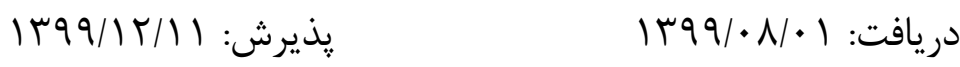

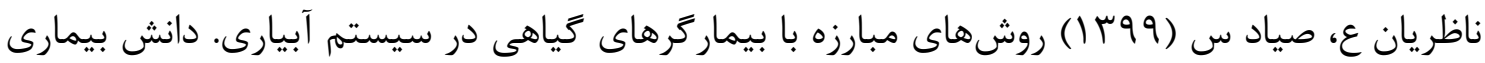

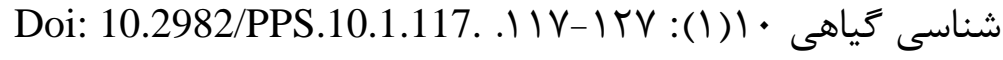

جكيده

بسيارى از بيمارگرهاى گياهى مىتوانند درون آب آبيارى در مزرعه، باغ يا گلخانهها انتشار يافته و

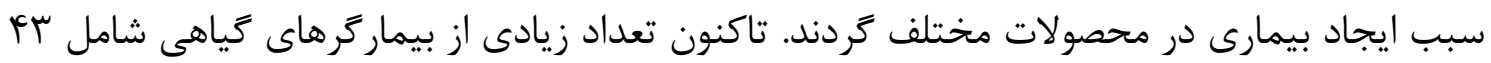

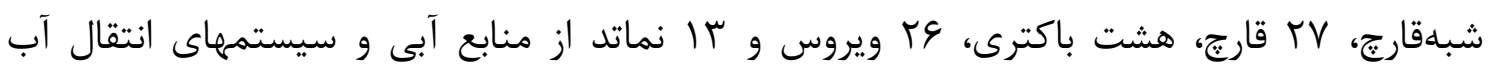

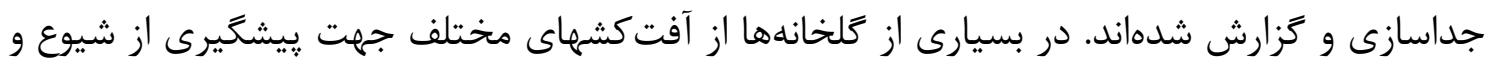

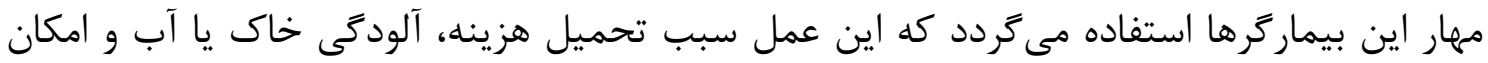

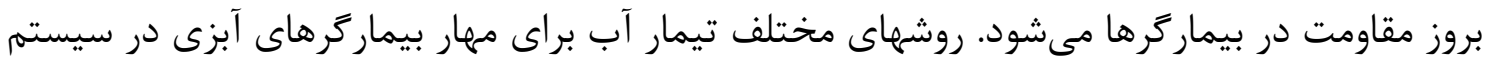

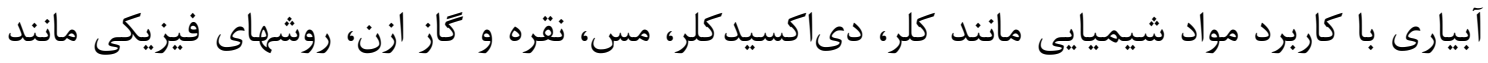

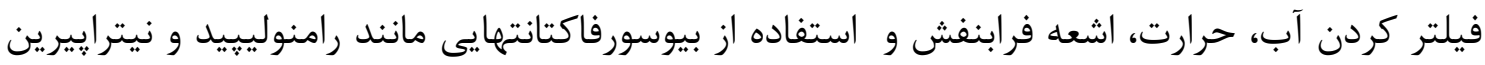
در اين مقاله شرح داده شدهاند. وازگًان كليدى: تيمار آب، بيمارگرهاى گياهى، بيوفيلم

\section{مقدمه}

آب آبيارى اغلب منبع مهم انتشار زادمايه تعداد زيادى از بيمارگرهاى گياهى ، جلبكها و نيز عوامل دخيل در تشكيل بيوفيلم (Biofilm) است (Hong and Moorman 2005, Scarlett et al. 2016). بيوفيلم تركيبى قييجيده متشكل از ريزجانداران بيماريزا و غيربيماريزا، تركيبهاى مترشحه از باكترىها نظير لييويلى ساكاريدها (LPSs) و اخزويلىساكاريدها (EPSs)، تركيبهاى ارگانيك داخل لولهها و كودهاى قابل حل مىباشد كه مواد غذايى را براى ساير ريزجانداران و موجودات تشكيل دهنده بيوفيلم ايجاد مى كند. بيوفيلمها با ايجاد سد فيزيكى سبب ممانعت از نفوذ آنتىبيوتيكها ومواد دفاعى مترشحه از طرف گياهان به درون سلولهاى عوامل بيماريزا شده و آنها را در مقابل عوامل محيطى مانند تغييرات pH، اشعه فرا بنفش، فشار اسمزى و روشهاى ضدعفونى محافظت مىنمايد 
(Berry et al. 2006, Bogino et al. 2013, Younis et al. 2019) بيشتر از طريق آبهاى سطحى، زهآب و آب بازيافتى به كياه ميزبان رسيده و منجر به بيمارى مىشوند. هر جند استفاده مجدد از آب آبيارى در سيستمهاى بسته در كلخانهها سبب صرفهجويى در هزينهها خواهد گرديد ولى استفاده و بازيافت مجدد از آب و مواد غذايى در جنين سيستمهايى خطر شيوع بيمارىهاى ناشى از بيماركرهاى آبزى را افزايش خواهد داد(Bandte et al. 2016) . جداسازى

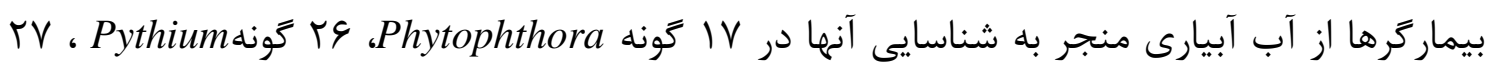

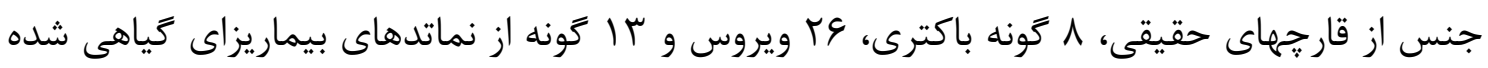
است (Aiello et al. 2017, Sevik 2011, Stewart-Wade 2011, Hong and Moorman 2005). ريزجانداران با هات متحرى مثل گونههاى Phytophthora و را مىتوان بهراحتى در آب Armillaria, Calonectria, Coniella, Fusarium, ييدا كرد. اما بيمارگرهايى مانند گونههاى Ilyonectria, Monosporoascus, Plectosphaerella, Rhizoctonia, Rosellinia, Sclerotinia, Thielaviopsis basicola , Sclerotium, Verticillium, Rhizoctonia solani, تازكدار هستند، نيز از راه خاك و بقاياى كياهى در آب انتفال مىيابند ( Baker and Matkin 1978 , Cacciola and Gullino 2019 ). جلبكها نيز مى توانند در آبهاى بى كيفيت رشد كرده و باعث اختلال در انتقال آب، مسدود شدن سيستمهاى آبيارى و كاهش رشد زياه با توليد مواد سمى شوند

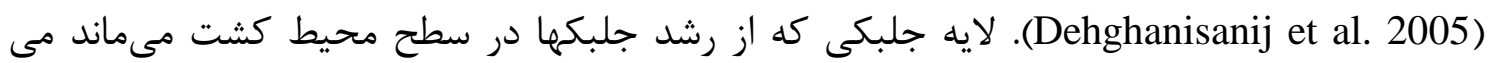
تواند ميزان نفوذ آب به محيط كشت گياه را كاهش دهد، همجنين جلبكها مىتوانند در مسير حركت كارگران مزاحمت ايجاد نموده و يا با يوشاندن سطوح كلدان زيبايى آن را كاهش دهند(Tekiner and Kurt 2019). روشهاى شيميايى در مهار بيمارگرهاى آبزى شامل كاربرد تركيبهايى نظير كلر، بر، ازون، يراكسيد هيدروزن و اسيد يراكسى استيك مىباشند ( Landa Fernández et al. 2019 ). روشهاى فيزيكى يا غير شيميايى شامل فيلتر كردن، استفاده از اشعه فرابنفش و گرما است (Banach et al. 2021). ميزان تأثير اين روشها روى ميكروبها بستخى به موجود هدف و ميزان غلظت و مدت استفاده از تركيبها و همجنين بستكى به پيارامترهاى كيفى آب مانند غلظت تركيبها ناخالص در آب، وجود يونها، pH و دما دارد (Stewart-Wade 2011). روشهاى تيمار آب براى مبارزه با بيماركرهاى تياهى ا-تيمار شيميايى

1-1- كلر: كلر يك تركيب اكسيدكننده بوده كه طى واكنشى با جذب يك الكترون تبديل به يون كلرايد مىشود. كلر بلصورت مايع، كاز و هيبيوكلريت سديم و يا اسيد هييوكلروس كه بلصورت جامد 
هستند، به آب اضافه مىشود. گزارشات متعددى از خسارت كلر بر روى گياهان در دست است. غلظت F r/F mg

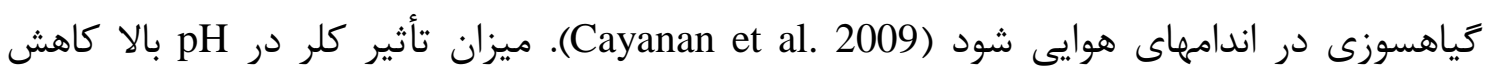
ميابد. بهترين اثرگذارى كلر در pH حدود \& است. يتانسيل اكسيداسيون و احياء ( Oxidation ) با ميزان قابليت اكسيد شدن در انتقال الكترون از سطح سلول و مرى (reduction potential=ORP بيمارگر اندازه گيرى مىشود. مرگ بيمارگرهاى گياهى در شرايط pH پائين و ORP بالا، بيشتر خواهد شد. ميزان pH و ORP و غلظت ماده مؤثره مى تواند بهترين تأثير را در عملكرد كلر داشته باشد. در عين حال بسيارى از كلكاران از آب با pH بالا براى آبيارى استفاده مىنمايند. كلر با تركيبهاى جون آمونيوم و نيتروزن داراى اثر متقابل بوده و در تركيب با اين مواد به فرم كلرامين تبديل خواهد شد. كلرامين نسبت به اسيد هييوكلروس داراى ماده مؤثره بهتر با ميزان بقا بيشتر در دماى بالاتراز ها درجه سلسيوس مىباشد. با اين وجود كلرامين نياز به مدت زمان تماس بيشترى نسبت به هييوكلروس براى تاثير گذارى روى بيمارگرهاى آبزى دارد. خياهسوزى در اثر كلرامين نيز كزارش شده است. در كشت هيدرويونيك كاهو، دراثرمصرف غلظت س mgl س/. در تركيب با

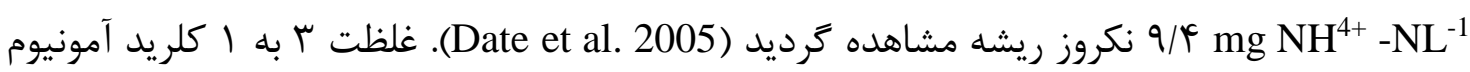
به هييوكلريت سديم بخاطر توليد كلرامين نسبت به استفاده از اسيد هييوكلروس بطور موثرى در كاهش حمله باكترىها تأثير داشته است (Le Chevallier et al. 1988). ا - ז-دى اكسيدكلر: عملكرد دى اكسيد كلر بهصورت اكسيد كنندگى بوده و در آب هيدروليز نشده و

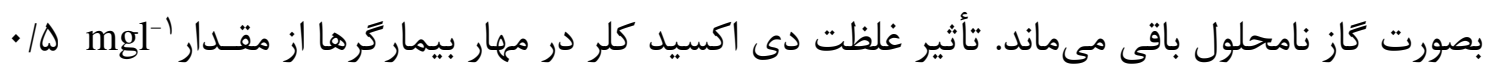

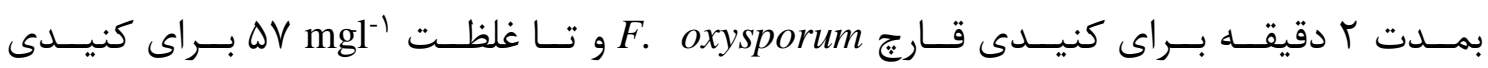

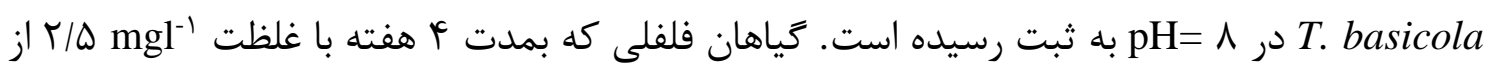
دى اكسيد كلر آبيارى شده بود، كاهش معنى دارى در ميزان رشـد از خـود نشـان نـداد. در كياهــان

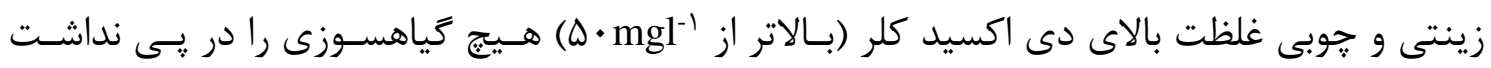
(Copes et al. 2003). علايم گياهسوزى با اين تركيب بهصورت زردى يا سوختكى نـوك بركمها و در مراحل پيشرفته بهصورت نكروز حاشيه و نوك بركما ظاهر مىشود. لكههاى نكروزه روى بر زمها و گلمها و

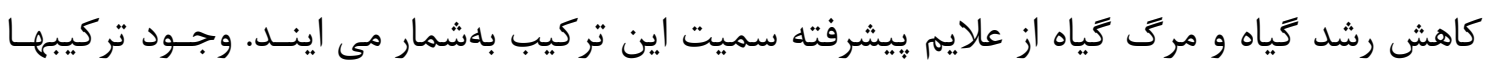

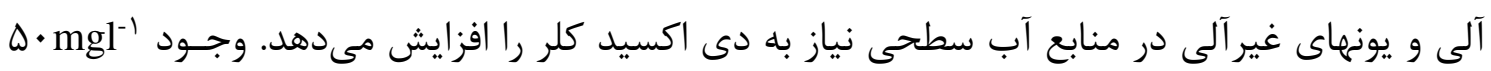
از تركيبها ييت در محلول ميزان نياز به دى اكسيد كلر را تا س/وس-ه/ كاه درصـد افـزايش خواهـد داد. دى اكسيد كلر نسبت به كلر حساسيت كمترى به تغييرات pH دارد. با اين وجود نياز بـه دى اكسـيد 
كلر در pH= 1 براى مهار بيماركر نسبت به هH= بيشتر است. تركيب مواد غذايى ميكرو با املاح آب (منكنز، كلسيم، بيوكربنات) و نيتروزن، غلظت دى اكسيد كلر مورد نياز براى مرك بيماركرهاى قارجى

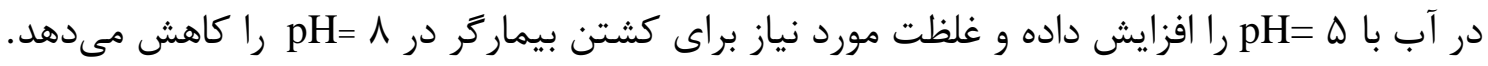

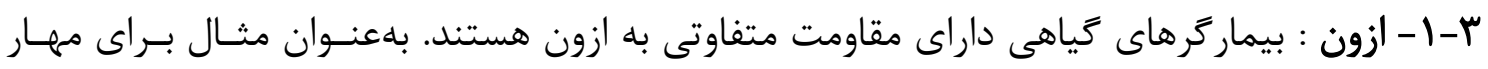

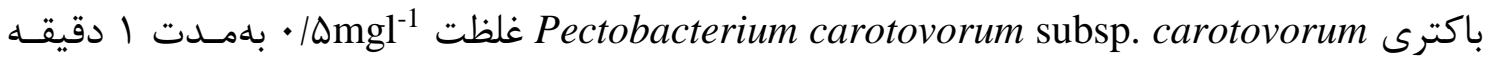
نياز است و براى ويروس موزاييك كوجافرنكى دوز

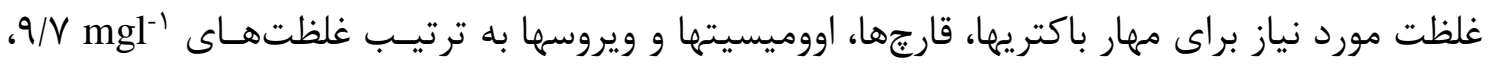

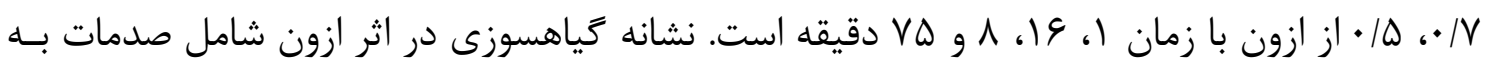

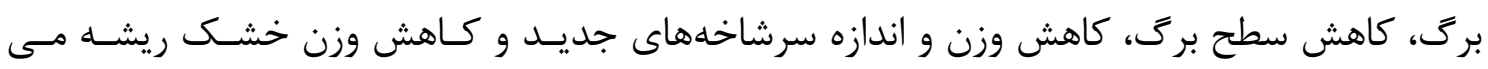

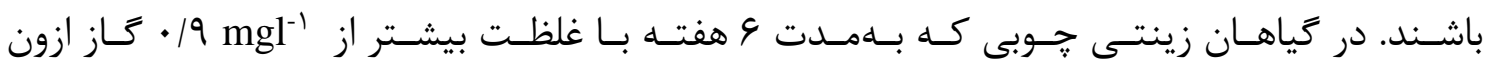

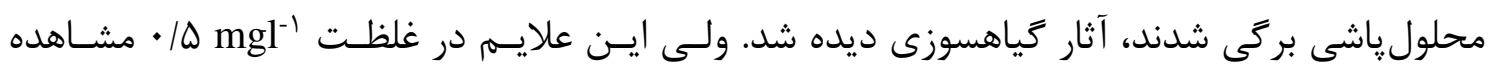

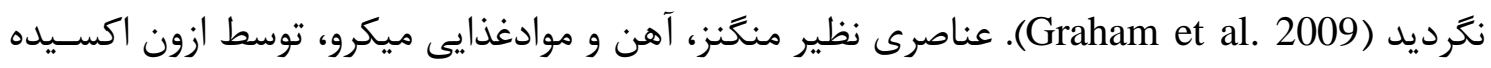

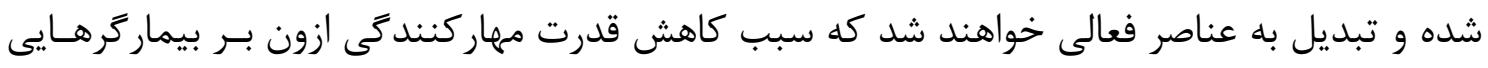
نظيـ Corynebacterium michiganense و مى . (2009 F-1- مس: مس جزو عناصر ضرورى براى رشد كياهان، موجودات تك سلولى و ير سلولى است. با اين

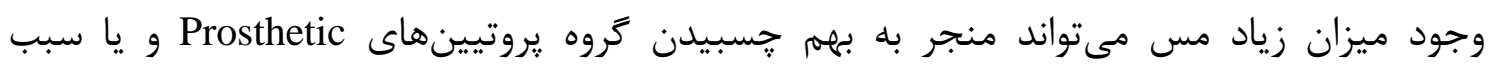

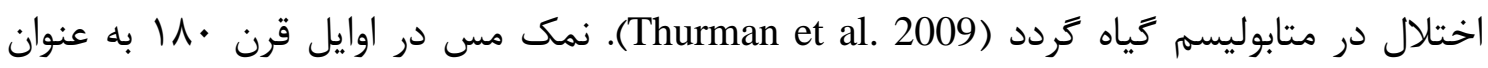
قارجكش بكار مىرفت و در اوايل قرن 19 براى از بين بردن جلبكها استفاده كرديد ( Thurman et al 2009). در بسيارى مواقع براى مهار زئوسيور قارج Phytophthora capsici با استفاده از قارجكشهاى تهاى مسى حندساعت زمان تماس سم با قارج نياز است (Granke and Hausbeck 2010) و همجنين براى مهار باكترى Erwinia carotovora subsp. carotovora نيز تماس קندساعته قار קكش مسى با

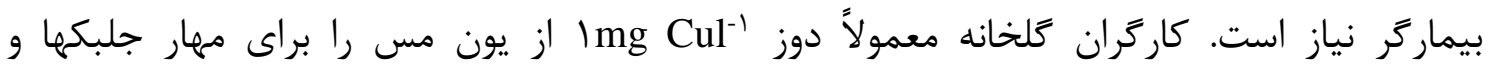

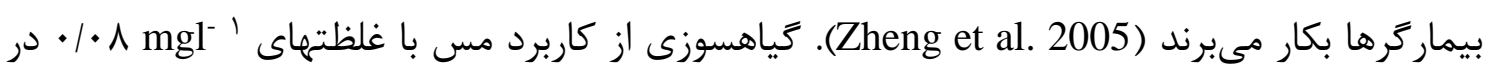

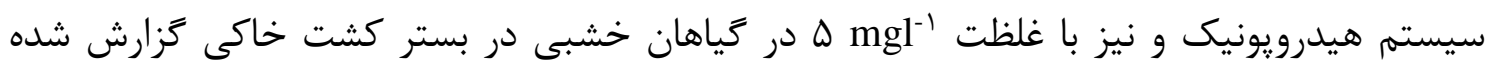

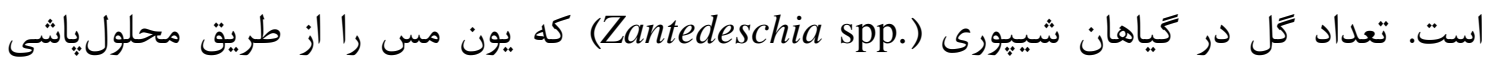

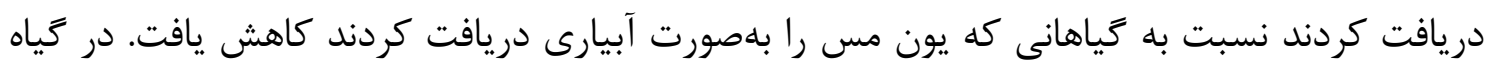

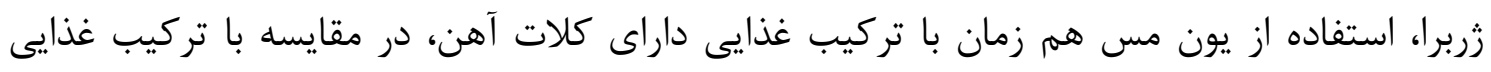


حاوى نمك آهن، اثر كمترى در مهار بيمارى يوسيدگى فيتوفترايى ريشه نشان داد Toppe and . Thinggaard 1998

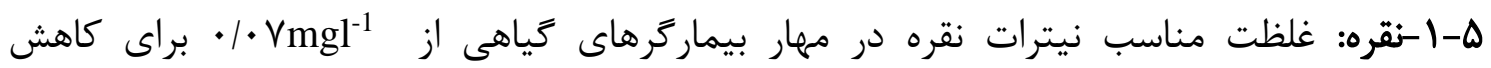

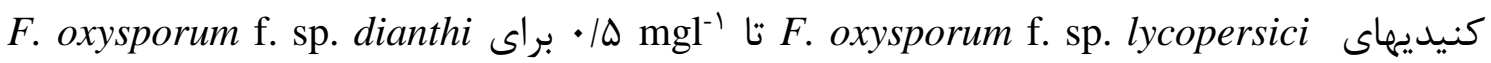
متغير است (Slade and Pegg 1993). كزارش شده كه يون نقره بر گونههاى آلترناريا، فوزاريوم و ويروس موزاييك توتون بى اثر است (Stewart-Wade 2011). كزارشهايى نيز در مورد استفاده از نقره و يا تركيب آن با مس براى ضدعفونى آب مصرفى براى توليد محصولهاى كلخانهاى وجود دارد (Stewart-Wade 2011). اثر منفى نقره ممكن است بلصورت بازارندكى از تاثير اتيلن، كاهش تعداد

كل و كاهش ارتفاع كياه در بعضى رقمهاى كياهان بروز نمايد (Bradford and Dilley 1978).

\section{r-روشهاى تيمار فيزيكى آب

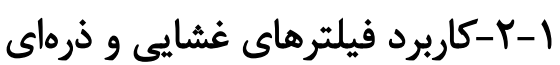

سازوكارهاى عملكرد فيلترها بصورت انبساط، انقباض، جداسازى، جسبندگى و تهنشين شدن مى في باشند. فيلترهاى مناسب براى جداسازى ريزجانداران از آب بايد داراى منافذى كوجى با قطر كمتر از

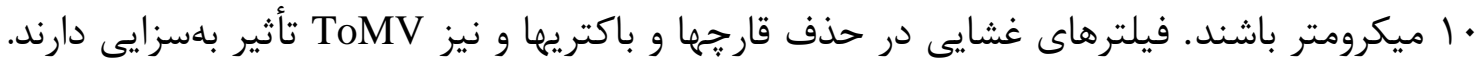
فيلتر غشايى زمانى كه بهصورت تركيب جند رديف فيلتر با اندازه منافذ از بزرك تا كوجى قرار مى

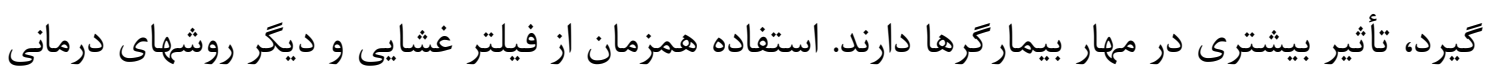
در بيماركرهاى آبزى، اثركذارى بالاترى در مهار دارد. فيلترهاى غشايى مىتوانند باعث نشست تركيبها

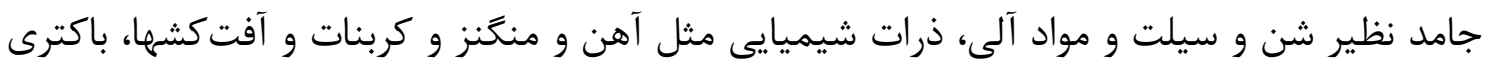
ها و جلبكها شوند. قبل از فيلتر كردن ذرات جامد بهتر است يك فيلتر اوليه انجام شود تا جلوى بستهشدن منافذ فيلتر اصلى كرفته شود. اسمز معكوس باعث حذف مواد غذايى از تركيب محلول غذايى شده و اين ويزگى منفى در زمانيكه تركيب غذايى بازيافت و دوباره استفاده مىشود اثركذار

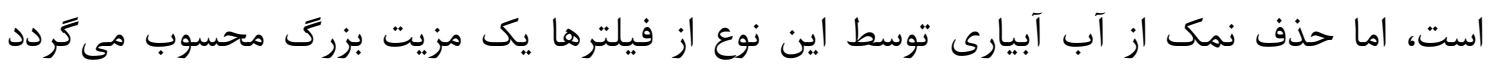

(Runia 1995)

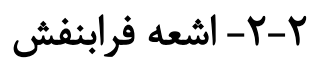

اشعه فرابنف (UV) باعث تخريب ساختمان RNA DNA مئشود. دامنه طيف نور UV بين

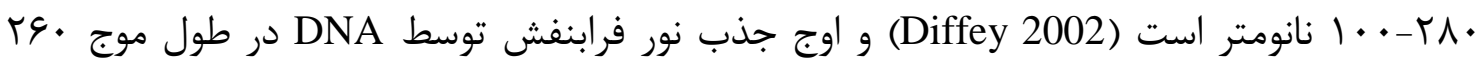

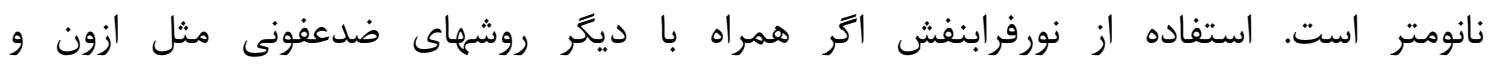

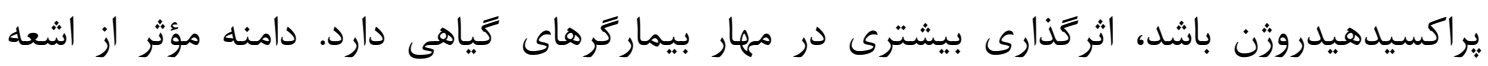


تابنفش براى مهار بيماركرها بين

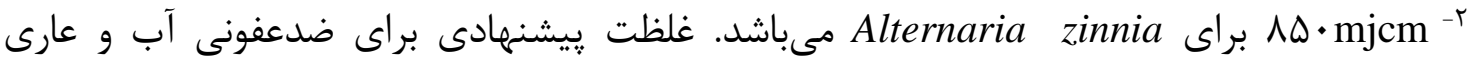

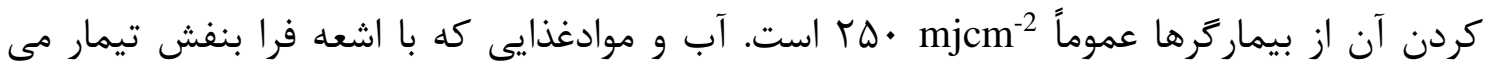
شوند بايد ناخالصى و مواد نامحلول كمى داشته باشند تا اجازه عبور •و درصد اشعه را بدهند. در جr نمونه آزمايش شده از خزانههاى استراليا، در سه مورد وضوح و شفافيت كافى در عبور اشعه فرابنفش مشاهده گرديد و حتى در مواردى كه از فيلتر ه ميكرونى استفاده گرديده بود وضوح لازم بلهدست نيامد. در آب كدر، به اشعه UV بالاترى نسبت به آب شفافتر نياز بوده تا همان ميزان اثر كشندكى را روى بيماركر ايجاد كند (Sutton et al. 2009). ميزان ذخيره آهن در كشت هيدرويونيك بعد از

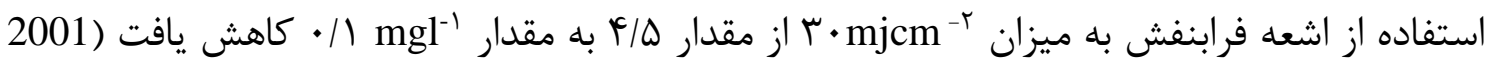
Albano and Miller نيست (Stewart- Wade 2011). همجنين استفاده از اشعه فرابنفش باقيمانده سمى يا توليدات سمى بدنبال نخواهد داشت.

$$
\text { r-r }
$$

دماى بالا يكيارجگى سلولى را بهمم ريخته و در فرآيند متابوليسم در ريزجانداران حساس، اختلال ايجاد مى كند (Crisan 1973). حرارت درمانى(ترموترايى) همجنين حركت ويروسها به سمت جوانه انتهايى را متوقف مىنمايد (Wang et al. 2008) روش تيمار حرارتى در مهار ريزجانداران در محصولهاى كلخانهاى بهدليل محدوديت مصرف مواد شيميايى در ارويا از امريكا متداولتر مىباشد (Runia and Amsing 2001). دامنه حرارتى مناسب در مهار بيمارگرها از • F درجه سلسيوس بمدت • 9 ثانيه براى زئوسيور Runia and Amsing 2001) Phytophthora cryptogea) تا له درجه سلسيوس بهمدت • ץ ثانيه براى Agrobacterium tumefacience متغير است (Poncet et al. 2001). حرارت با مواد غذايى كمتر وارد واكنش مىشود و مواد شيميايى از خود به جا نمى گذارد، با اين حال ممكن است ته نشست نمك در سيستم آبيارى ايجاد نمايد (Runia 1995).

\section{r- استفاده از بيوسورفاكتانتها}

رامنوليييد (Rhamnolipid) و نيترإيرين (Nitrapyrin) دو نوع بيوسورفاكتانت بوده كه براى تيمار آب بكار مىروند. سورفاكتانت رامنوليييد يك نوع قارجكش طبيعى است كه از باكترى Pseudomonas aeruginosa باعث افزايش باكتريهاى مفيد (Pseudomonas putida) در محلول بازيافتى مى گردد. نيترإيرين به 
عنوان تثبيت كننده نيتروزن نيز به ثبت رسيده است (Pagliaccia et al. 2007). تحقيقى نشان داده

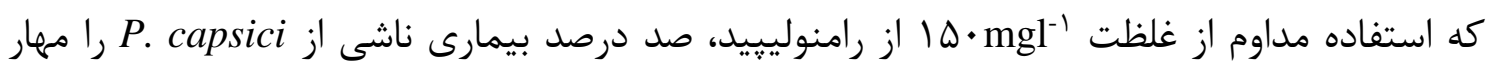
مى كند. تغذيه با نيتراييرين باعث كاهش • P درصدى بوته ميرى خيار در اثر P. aphanidermatum نسبت به تيمار شاهد نيز مى بيوسورفاكتانت رامنوليييد و نيتروييرين تيمار شده بود باعث افزايش غلظت باكتريهاى مفيد نسبت به تيمار بدون بيوسورفاكتانت گرديد Pagliaccia et al. putida 2007 (). افزايش باكتريهاى مفيد به عنوان دومين فايده استفاده از بيوسورفاكتانتها بوده، در عين حال وجود جمعيت بالاى باكترى إبب تشكيل بيوفيلم و افزايش مسدود شدن مسير آبيارى خواهد زرديد. غلظت آ. رامنوليييد، زمانى كه بصورت هوايى و يا آبيارى در محيط كشت آلى و راكوول استفاده گرديد، منجر

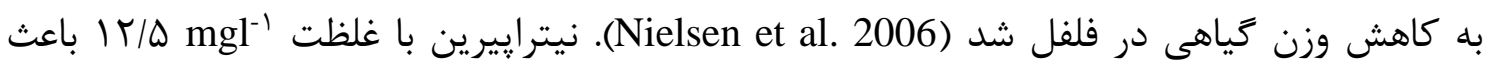
كاهش رشد فلفل شده و منجر به كلروز گرديد (Pagliaccia et al. 2007).

\section{نتيجه}

مديريت بيمارگرهاى گياهى در سيستم آبيارى به عواملى مانند: منبع آب، سرعت و حجم روان آب، دما، مواد آلى و غير آلى، pH، نوع ماده تشكيل دهنده سيستهم آبيارى، حساسيت گياه به خياهسوزى و هزينه دارد. براى از بين بردن بيمارگرها مىتوان از روشهاى فيزيكى، شيميايى، حرارت درمانى و يا بيوسورفكتانتها بهتنهايى و يا تواما استفاده كرد. امروزه تيمار آب به عنوان يكى از روشهاى افزايش توليد محصولات كشاورزى، باغى و گلخانهاى، با هدف كاهش خسارت مالى ناشى ازآلودگى به بيماركرها، بيوفيلمها و جلبكها شناخته شده است. مجموعه يزوهشهاى علمى انجام گرفته نشان مى دهد كه ريزجانداران هدف داراى تنوع مقاومت به روشهاى تيمار آب بوده و استفاده از يك روش مديريتى بهتنهايى در تيمار آب نمىتواند بلصورت مناسب روى بيمارگرهاى مقاوم اثر گذار باشد. بنابراين كاشت رقمهاى مقاوم، بررسى اوليه كيفيت آب، مطابقت زمانى نياز آبى گياه و آبيارى و محدود نمودن استفاده از آفت كشهها، به همراه كاربرد روشهاى مبارزه با بيمارگرهاى گياهى، براى توليد محصول سالم بيشنههاد مىشود.

\section{References}

Aiello D, Guarnaccia V, Formica PT, Hyakumachi M, Polizzi G (2017) Occurrence and characterisation of Rhizoctonia species causing diseases of ornamental plants in Italy. European Journal of Plant Pathology 148:967-982. 
Albano JP, Miller WB (2001) Photo degradation of FeDTPA in nutrient solutions. I. Effects of irradiance, wavelength, and temperature. Horticultural Science 36:313316.

Baker KF, Matkin OA (1978) Detection and control of pathogens in water. Ornamentals Northwest Newsletter 2:12-14.

Banach JL, Hoffmans Y, Appelman WAJ, Van Bokhorst-van de Veen H, van Asselt ED (2021) Application of water disinfection technologies for agricultural waters. Agricultural Water Management 2:1-9

Bandte M, Rodriguez MH, Schuch I, Schmidt U, Buettner C (2016) Plant viruses in irrigation water: reduced dispersal of viruses using sensor-based disinfection. Irrigation Science 34:221-229.

Bates ML, Stanghellini ME (1984) Root rot of hydroponically grown spinach caused by Pythium aphanidermatum and $P$. dissotocum. Plant Disease 68:989-991.

Berry D, Xi C, Raskin L (2006) Microbial ecology of drinking water distribution systems. Current Opinion in Biotechnology 17:297-302.

Bogino PC, Oliva MDLM, Sorroche FG, GiordanoW (2013) The role of bacterial biofilms and surface components in plant-bacterial associations. International Journal of Molecular Sciences 14:15838-15859.

Bradford KJ, Dilley DR (1978) Effects of root anaerobiosis on ethylene productions, epinasty, and growth of tomato plants. Plant Physiology 61:506-509.

Cacciola SO, Gullino ML (2019). Emerging and re-emerging fungus and oomycete soilborne plant diseases in Italy. Phytopathologia Mediterranea 58:451-472.

Cayanan DF, Zhang P, Liu W, Dixon M, Zheng Y (2009) Efficacy of chlorine in controlling five common plant pathogens. Horticultural Science 44:157-163.

Copes WE, Chastagner GA, Hummel RL (2003) Toxicity responses of herbaceous and woody ornamental plants to chlorine and hydrogen dioxides. Plant Health Progress 4:1-9

Crisan EV (1973) Current concepts of thermophilism and the thermophilic fungi. Mycologia 65:1171-1198.

Date S, Terabayashi S, Kobayashi Y, Fujime Y (2005) Effects of chloramines concentration in nutrient solution and exposure time on plant growth in hydroponically cultured lettuce. Scientia Horticulturae 103:257-265.

Dehghanisanij H, Yamamoto T, Ould Ahmad B, Fujiyama H, Miyamoto K (2005) The effect of chlorine on emitter clogging induced by algae and protozoa and the performance of drip irrigation. American Society of Agriculture and Biological Engineers 48:519-527.

Diffey BL (2002) Sources and measurement of ultraviolet radiation. Methods 28:4-13.

Graham T, Zhang P, Zheng Y, Dixon MA (2009) Phytotoxicity of aqueous ozone on five container-grown nursery species. Horticultural Science 44:774-780.

Granke LL, Hausbeck MK (2010) Effects of temperature, concentration, age, and algaecides on Phytophthora capsici zoospore infectivity. Plant Disease 94:54-60. 
Hong CX, Moorman GW (2005) Plant pathogens in irrigation water: challenges and opportunities. Critical Review in Plant Science 24:189-208.

Landa Fernández IA, Monje-Ramirez I, Orta Ledesma de Velásquez MT (2019). Tomato Crop Improvement Using Ozone Disinfection of Irrigation Water. Ozone: Science and Engineering 41:398-403.

Le Chevallier MW, Cawthon CD, Lee RG (1988) Inactivation of biofilm bacteria. Applied Environmental Microbiology 54:2492-2499.

Nielsen CJ, Ferrin DM, Stanghellini ME (2006) Efficacy of biosurfactants in the management of Phytophthora capsici on pepper in recirculating hydroponic systems. Canadian Journal of Plant Pathology 28:450-460.

Ohashi-Kaneko K, Yoshii M, Isobe T, Park JS, Kurata K, Fujiwara K (2009) Nutrient solution prepared with ozonated water does not damage early growth of hydroponically grown tomatoes. Ozone: Science in Engineering 31:21-27.

Pagliaccia D, Ferrin D, Stanghellini ME (2007) Chemo-biological suppression of root infecting zoosporic pathogens in recirculating hydroponic systems. Plant Soil 299(12): 163-179.

Poncet C, Offroy M, Bonnet G, Brun R (2001) Disinfection of recycling water in rose cultures. Acta Horticulturae 547:121-127.

Runia WT, Amsing JJ (2001) Lethal temperatures of soil borne pathogens in recirculation water from closed cultivation systems. Acta Horticulturae 554:333-339.

Runia WTh (1995) A review of possibilities for disinfection of recirculation water from soilless cultures. Acta Horticulturae 382:221-229.

Scarlett K, Collins D, Tesoriero L, Jewell L, Van Ogtrop F, Daniel R (2016) Efficacy of chlorine, chlorine dioxide and ultraviolet radiation as disinfectants against plant pathogens in irrigation water. European journal of plant pathology 145:27-38.

Sevik MA (2011) Water pollution: water-borne plant viruses. Erciyes Üniversitesi Fen Bilimleri Enstitüsü Dergisi 27:40-47.

Slade SJ, Pegg GF (1993) The effect of silver and other metal ions on the in vitro growth of root rotting Phytophthora and other fungal species. Annals of Applied Biology 122: 233-251.

Stewart-Wade SM (2011) Plant pathogens in recycled irrigation water in commercial plant nurseries and greenhouses: their detection and management. Irrigation Science 29:267-297.

Sutton JC, Yu H, Grodzinski B, Johnstone M (2009) Relationships of ultraviolet radiation dose and inactivation of pathogen propagules in water and hydroponic nutrient solutions. Canadian Journal of Plant Pathology 22:300-309.

Tekiner M, Ak İ, Kurt M (2019) Impact of UV-C radiation on growth of micro and macro algae in irrigation systems. Science of The Total Environment 672:81-87.

Thurman RB Gerba CP, Bitton G (2009) The molecular mechanisms of copper and silver ion disinfection of bacteria and viruses. Critical Review of Environmental Science Technology 18:295-315. 
Toppe B, Thinggaard K (1998) Prevention of Phytophthora root rot in gerbera by increasing copper ion concentration in the nutrient solution. European Journal of Plant Pathology 104:359-366.

Wang QC, Cuellar WJ, Rajamäki ML, Hiraka Y, Valkonen JPT (2008) Combined thermotherapy and cryotherapy for virus eradication: relation of virus distribution, subcellular changes, cell survival and viral RNA degradation in shoot tips to efficient production of virus-free plants. Molecular Plant Pathology 9:237-250.

Younis BA, Mahoney L, Schweigkofler W, Suslow K (2019) Inactivation of plant pathogens in irrigation water runoff using a novel UV disinfection system. European Journal of Plant Pathology 153:907-914.

Zheng Y, Wang L, Dixon M (2005) Greenhouse pepper growth and yield response to copper application. HortScience 40:2132-2134. 